Egyptian Journal of Rabbit Science, 29 (1): 61 - 78(2019)

\title{
FACTORS AFFECTING MILK PRODUCTION AND USING APPLICATION SELECTION INDICES TO IMPROVE PRODUCTIVETRAITS OF DOES IN NEW ZEALAND WHITE RABBITS.
}

\author{
Amira S. El-Deghadi. \\ Animal Production Research Institute, Agriculture Research Center, Ministry of \\ Agriculture, Dokki, Cairo, Egypt.
}

This study was carried out on 765 litters of New Zealand White(NZW)rabbit breed and extended for about 5years to study some factors affecting milk traits. The effect of season of kindling on milk production was higher significantly during most of the weeks of the study and total milk yield. The insignificant effect of parity on milk production and the milk yield during $1^{\text {st }}, 3^{\text {rd }}$ week and total milk yield but increased gradually with the advancement of parity from $1^{\text {st }}$ to $3^{\text {rd }}$ parity and decreased for other parities. Increasing the litter size from 3 to 9 was associated with a significant increase for milk production during $1^{\text {st }}, 2^{\text {nd }}, 3^{\text {rd }}, 4^{\text {th }}$ week and total milk yield. Teats number were significant in milk yield during most of weeks and total milk yield of the study. Genetic correlation between litter size at birth and litter weight were positive and high and ranging from 0.48 to 0.66.Genetic correlations between litter size at birth and litter weight at weaning were low while the phenotypic correlations were positive and high and ranging from 0.34 to 0.74. Selection indices for litter and milk traits were constructed incorporating litter size at birth $\left(X_{1}\right)$, litter size at weaning $\left(X_{2}\right)$, litter weight at birth $\left(X_{3}\right)$, litter weight at weaning $\left(X_{4}\right)$ and pre-weaning mortality $(X 5)$, milk yield during the $1^{\text {st }}, 2^{\text {nd }}, 3^{\text {rd }}$ and $4^{\text {th }}$ week $\left(X_{1}, X_{2}, X_{3}, X_{4}\right)$ and total milk yield $\left(X_{5}\right)$ to improvement of productivity of does of New Zealand White rabbits. Relative efficiencies $\left(R_{I H}\right)$ in litter traits were high for $I_{1}$ (based on five traits) to other indices

Relative efficiency $\left(R_{I H}\right)$ in milk traits were high for $I_{2}$ (based on four traits) to other indices and recommended for use to maximize response and apply selection on this index. The expected genetic gain changes in litter size at birth was low in all of the indices used and ranging from -0.031 to 0.129 young, in litter size at weaning was low and ranging from 0.065 to 0.100 young, in litter weight at birth was 
moderate or high and ranging 3.71 to $9.34 \mathrm{~g}$, in litter weight at weaning was high and ranging 108.99 to $131.65 \mathrm{~g}$ and in pre-weaning mortality was ranging 0.282 to 1.30 young. The expected genetic gain changes were high in milk yield during the $1^{\text {st }}, 2^{\text {nd }}, 3^{\text {rd }}, 4^{\text {th }}$ week and total milk yield and ranging 14.39 to $34.77 \mathrm{~g}, 42.33$ to $54.26 \mathrm{~g}, 83.71$ to $105.66 \mathrm{~g}$, 10.45 to $32.70 \mathrm{~g}$ and 143.60 to $151.76 \mathrm{~g}$.

Conclusively, Milk production was higher in winter months than other seasons. For litter traits recommended for use to maximize response and apply selection on index $I_{1}$ (based on five traits).For milk traits recommended for use to maximize response and apply selection on this index, $I_{2}$ (based on four traits).

Key words: Genetic and phenotypic correlation, selection indices.

In general, rabbit does nurse the kits once-a-day for 3-4 minutes. During this time the kits are able to consume their daily feed requirement, which is about equal to $1 / 6$ of their body weight. The milk intake, body weight gain and survival of the kits depend on the milk production and their mother nursing willingness. However, the does are not able to cover the nutrient requirements of the suckling kits, especially on the 3rd week of lactation (Kacsala et al., 2015). The main points in rabbit production is how to achieve optimum growth rate and growth in rabbit is mainly affected by the growth gain during suckling period especially during the first three weeks of life, so for successful rabbit production a great interest must be focused on the newborn bunnies especially during their suckling period, which directly affect later on their growth rate. Lactation can be used as an evaluating factor for the reproductive efficiency of the doe. Rabbits milk yield varies according to physiological, inherited and environmental factors which increases till the $3^{\text {rd }}$ week, then decreases. The goal of this study is to examine some factors affecting milk production in rabbit is as important as many deaths and growth disturbances in young bunnies may be occurred due to shortage in milk production to help us to solve many problems related to milk yield in rabbit farms such as parity of kindling, season of birth, litter size at birth, teat number and dam body weight.

For the improvement of genetic value of livestock, individuals with the best breeding values have to be chosen as the parents of the next generation. Therefore the application of selection indices may be a good solution to the problem mentioned since profitability is an appropriate 
parameter to express the importance of the traits in the final evaluation (Gyovai et al., 2012). Therefore, the aims of the selection index method are to maximize the genetic progress towards a stated economic goal and also find an application of selection indices improve of the productivity of rabbits does.

\section{MATERIALS AND METHODS}

\section{Animals and data:}

The data of the present study collected on 765 litters for five consecutive years from the Rabbitry of Faculty of Agriculture at Moshtohor, Benha University, on New Zealand White( NZW ) rabbits breed. .Mating, according to the breeding plan, a buck was assigned at random for every 3-4 does for mating with a restriction of avoiding full sib, half sib and parentoffspring mating. The statistical analysis was carried out by weighed leastsquares means method in the procedure GLM of statistical software SAS ( 2003) to obtain least squares and used to compare means by Duncan's multiple range test for milk yield during the $1^{\text {st }}, 2^{\text {nd }}, 3^{\text {rd }}$ and $4^{\text {th }}$ week (MY1, MY2, MY3 and MY4) and total milk yield (TMY) respectively;.

Where:

$$
Y_{i j k l}=\mu+S_{i}+P_{j}+L_{k}+T_{1}+e_{i j k l} \quad \text { (Model1). }
$$

$Y_{i j k l}=$ the observation on the $i j k 1^{\text {th }}$ milk traits, $\mu=$ the overall mean, $S_{i}=$ the fixed effect of the $i^{\text {th }}$ season ( $i=1,2$ and 3$), P_{j}=$ the fixed effect of the $i^{\text {th }}$ parity $(1=1, \ldots . .5), \mathrm{L}_{\mathrm{k}}=$ the fixed effect of the $\mathrm{k}^{\text {th }}$ litter size at birth $\left(\mathrm{k}^{\text {th }}=\leq 3 \ldots \geq 9\right)$, $\mathrm{T}_{1}=$ the fixed effect of the $1^{\text {th }}$ teat number $\left(1^{\text {th }}=7,8,9\right.$ and10and $e_{i j k l}=$ the random deviation of all the other effects no specified the model. The model without interaction between different fixed effects to presence of complete confounding between factor in model.

Starting mixed model was obtained applying REML method of VARCOMP procedure of SAS 2003. Data were analyzed using multi-trait animal model of litter and milk traits using MTDFREML programs of Boldman et al.,1995, to obtain phenotypic and genetic variances and covariance and heritability to use for calculating selection indices for litter and milk traits given in Table $4 \& 5$. Analyses were done according to the general model:

$$
\mathbf{y}=\mathbf{X b}+\mathbf{Z}_{1} \mathbf{a}+\mathbf{Z}_{2} \mathbf{p}+\mathbf{e} . \quad(\text { Model 2) }
$$

Where, $y=$ Vector of observation, $X=$ Incidence matrix of fixed effects; $b=$ vector of fixed effects including season (3 levels) and parity (4 levels); $Z_{1}$ and $\mathrm{Z}_{2}=$ incidence matrices corresponding to random effects of additive (a) and permanent environment ( $p_{e}$, doe effect), respectively; Heritability were 
computed as additive direct $\left(h^{2}{ }_{a}=\sigma_{a}^{2} / \sigma_{p}^{2}\right)$ where $\sigma^{2} a$ and $\sigma^{2} p$ are the variances due to effects of additive genetic and phenotypic.

\section{Selection Indices:}

Different selection indices for litter and milk traits were constructed using MINTAB, (1991). The indices values were calculated as $I=\sum_{i}^{n}\left(b_{i}\right.$ $\mathrm{p}_{\mathrm{i}}$ )where $\mathrm{I}$ is selection index, $\mathrm{b}_{\mathrm{i}}$ is a selection index weighing factor, $\mathrm{p}_{\mathrm{i}}$ is a phenotypic measure and $n$ is number of traits. Hazel (1943) proved that maximum $r_{H I}$ is achieved then optimal index weights (b) was calculated for each of the objectives as:

$$
\mathrm{b}=\mathrm{P}^{-1} \mathrm{Ga} \text {, }
$$

Where: $\mathrm{P}^{-1}$ is the inverse of the phenotypic (co)variance matrix of the traits in the selection index, $G$ is the genetic covariance the economic values for the goal traits. Furthermore the other different properties of the selection index were calculated as following: Standard deviation of the index, $\sigma_{\mathrm{I}}=\sqrt{ } \mathrm{b}^{\prime} \mathrm{Pb}$, Standard deviation of the aggregate genotype, $\sigma_{\mathrm{H}}=\sqrt{\mathrm{a}} \mathrm{Ga}$, Correlation between the index and the aggregate genotype (accuracy) $R_{I H}=\sigma_{I} / \sigma_{H}$.

Relative economic value were calculated by Lamont method (1991) the method depending on heritability estimates of the all traits, where, $\mathrm{T} / \mathrm{h}_{\mathrm{i}}{ }^{2}$, where $; \mathrm{T}=$ summation for heritability of different litter and milk traits.

\section{RESULTS AND DISCUSSION}

\section{Season effect:}

The effect of season of kindling on milk production are presented in Table 1 obtained data declared that milk production was higher significantly $(\mathrm{P} \leq 0.01)$ during most of the weeks of the study and total milk yield except during the fourth one were the effected was not significant. Milk production was higher in winter months than other seasons.

The significant increase in the milk production during winter months may be attributed to suitability of the environmental conditions to rabbit production, increase in food consumption and abundance of green fodders during winter months. These results agreement with, Ayyat et al.,1995, also Ahmed, 1997 reported that the highest milk yield was recorded during winter while the lowest milk yield was produced during Spring. with NZW and California (CAL) rabbits. 
Table 1. Least-squares means and standard errors of milk yield (g) traits as affected by season, parity, litter size at birth and teat number for NZW rabbits.

\begin{tabular}{|c|c|c|c|c|c|c|}
\hline Fixed effect & No. & MY1 & MY2 & MY3 & MY4 & TMY \\
\hline Overall Mean & 765 & $810 \pm 37$ & $962 \pm 43$ & $1020 \pm 51$ & $465 \pm 42$ & $3237 \pm 126$ \\
\hline \multicolumn{7}{|c|}{ Season } \\
\hline Winter & 217 & $837 \pm 24^{a}$ & $1022 \pm 29^{a}$ & $1118 \pm 34^{\mathrm{a}}$ & $500 \pm 28$ & $3466 \pm 83^{\mathrm{a}}$ \\
\hline Spring & 245 & $790 \pm 22^{\mathrm{ab}}$ & $951 \pm 26^{\mathrm{b}}$ & $997 \pm 31^{b}$ & $454 \pm 25$ & $3188 \pm 75^{\mathrm{b}}$ \\
\hline Autumn & 303 & $788 \pm 23^{b}$ & $913 \pm 27^{b}$ & $1053 \pm 32^{\mathrm{b}}$ & $502 \pm 27$ & $3224 \pm 80^{b}$ \\
\hline Sig. test & & Not Sig. & $* *$ & $* *$ & Not Sig. & $* *$ \\
\hline \multicolumn{7}{|c|}{ Parity } \\
\hline 1 & 269 & $800 \pm 23$ & $973 \pm 27$ & $1014 \pm 32$ & $501 \pm 26$ & $3267 \pm 79$ \\
\hline 2 & 261 & $815 \pm 21$ & $956 \pm 25$ & $1072 \pm 29$ & $483 \pm 24$ & $3336 \pm 72$ \\
\hline 3 & 162 & $844 \pm 26$ & $960 \pm 31$ & $1103 \pm 37$ & $499 \pm 30$ & $3408 \pm 90$ \\
\hline 4 & 73 & $762 \pm 37$ & $958 \pm 44$ & $1034 \pm 52$ & $459 \pm 43$ & $3160 \pm 128$ \\
\hline Sig. test & & Not Sig. & Not Sig. & Not Sig. & Not Sig. & Not Sig. \\
\hline \multicolumn{7}{|c|}{ Litter size at birth } \\
\hline$\leq 3$ & 38 & $685 \pm 49^{c}$ & $882 \pm 58^{\mathrm{c}}$ & $910 \pm 69^{c}$ & $389 \pm 56^{\mathrm{b}}$ & $2852 \pm 169^{d}$ \\
\hline 4 & 60 & $786 \pm 39^{\mathrm{ab}}$ & $873 \pm 46^{\mathrm{c}}$ & $988 \pm 55^{\mathrm{bc}}$ & $435 \pm 45^{\text {ab }}$ & $3070 \pm 136^{\text {cd }}$ \\
\hline 5 & 100 & $777 \pm 31^{\mathrm{b}}$ & $926 \pm 36^{\mathrm{bc}}$ & $1052 \pm 43^{\mathrm{ab}}$ & $483 \pm 35^{\mathrm{ab}}$ & $3251 \pm 106^{c}$ \\
\hline 6 & 141 & $799 \pm 28^{a} b$ & $962 \pm 32^{\mathrm{bc}}$ & $1100 \pm 39^{a b}$ & $487 \pm 32^{\mathrm{ab}}$ & $3346 \pm 96^{\mathrm{abc}}$ \\
\hline 7 & 143 & $856 \pm 27^{\mathrm{ab}}$ & $990 \pm 32^{\mathrm{ab}}$ & $1082 \pm 38^{\mathrm{ab}}$ & $537 \pm 31^{\mathrm{a}}$ & $3424 \pm 94^{\mathrm{ab}}$ \\
\hline 8 & 134 & $863 \pm 27^{\mathrm{ab}}$ & $1030 \pm 32^{\mathrm{ab}}$ & $1127 \pm 38^{\mathrm{a}}$ & $551 \pm 31^{\mathrm{a}}$ & $3530 \pm 93^{\mathrm{ab}}$ \\
\hline$\geq 9$ & 149 & $870 \pm 27^{\mathrm{a}}$ & $1068 \pm 32^{\mathrm{a}}$ & $1131 \pm 38^{\mathrm{a}}$ & $517 \pm 31^{\mathrm{a}}$ & $3578 \pm 92^{\mathrm{a}}$ \\
\hline Sig. test & & $* *$ & $* * *$ & $* *$ & $* *$ & $* * * *$ \\
\hline \multicolumn{7}{|c|}{ Teat number } \\
\hline 7 & 62 & $782 \pm 39^{\mathrm{b}}$ & $951 \pm 45$ & $980 \pm 54^{\mathrm{b}}$ & $429 \pm 44^{b}$ & $3111 \pm 133^{b}$ \\
\hline 8 & 395 & $803 \pm 18^{\mathrm{ab}}$ & $926 \pm 21$ & $1025 \pm 25^{\mathrm{ab}}$ & $482 \pm 20^{\mathrm{ab}}$ & $3207 \pm 61^{\mathrm{ab}}$ \\
\hline 9 & 132 & $799 \pm 27^{\text {ab }}$ & $980 \pm 32$ & $1107 \pm 38^{\mathrm{a}}$ & $530 \pm 31^{\mathrm{a}}$ & $3418 \pm 94^{\mathrm{a}}$ \\
\hline 10 & 176 & $838 \pm 24^{\mathrm{a}}$ & $990 \pm 28$ & $1111 \pm 33^{\mathrm{a}}$ & $500 \pm 28$ & $3434 \pm 82^{\mathrm{a}}$ \\
\hline Sig. test & & $* *$ & Not Sig. & $* *$ & $* *$ & $* *$ \\
\hline
\end{tabular}

MY1, MY2, MY3 and MY4 $=$ milk yield during the $1^{\text {st }}, 2^{\text {nd }}, 3^{\text {rd }}$ and $4^{\text {th }}$ week respectively and $\mathrm{TMY}=$ Total milk yield ${ }^{->c}$ : Any two means having the same superscript are not significantly different using Duncan's Multiple Range test $(\mathrm{P} \leq 0.01$ or $\mathrm{P} \leq 0.001$; Duncan 1955).

Soliman, (2008) who found that the decrease in milk production during hot climate may be due to reduce in appetite and food intake. Abd El-monem, (2009)found that milk production was decreased in summer than winter under Egyptian conditions. Mahmoud, (2013) found that The effect of kindling season on milk production was higher significantly $(\mathrm{P}<0.05)$ in winter months in both single and double lactation than summer months except during the $3{ }^{\text {rd }}$ week of single lactation where there was an increase in the milk yield during winter months than that of the summer months but this increase was not significant. 


\section{Parity effect:}

In generally the insignificant effect of parity on milk production are presented in Table 1 . The milk yield during $1^{\text {st }}, 3^{\text {rd }}$ week and total milk yield increased gradually with the advancement of parity from $1^{\text {st }}$ to $3^{\text {rd }}$ parity and decreased for other parities. Similar results were also obtained by Iraqi and Youssef, 2006 they reported that effect of parity for most of milk production traits increased with the advancement of parity from the $1^{\text {st }}$ to $3^{\text {rd }}$ parity, then relatively decreased from 3 to 5 parity and increased again to reach the peak at $7^{\text {th }}$ parity. From these results the tendency was compatible with mammary gland advancement and the physiological state of the does (El-Sayiad, 1994).

\section{Litter size at birth effect:}

Litter size at birth was important factor determining milk production in rabbit, as increasing the litter size from 3 to 9 was associated with a significant increase $(\mathrm{P} \leq 0.01$ or $\mathrm{P} \leq 0.001)$ in the milk production during $1^{\text {st }}, 2^{\text {nd }}, 3^{\text {rd }}, 4^{\text {th }}$ week and total milk yield (Table 1), the higher milk production in the does with larger litters might be due to the increase in the amount of milk consumed by increasing the number of young which stimulate the mammary gland to increase its production from milk. McNitt and Lukefahr (1990) reported that, as the number of bunnies the litter increased, milk yield increased in a curvilinear manner ( $\mathrm{P}<0.01)$.Mahmoud,( 2013) found that the effect of litter size at birth was significant and important factor determining milk production in rabbit, as increasing the litter size from 4 to 6 then to 8 and the higher milk production in the does with larger litters. Kolawole et al.,(2013) determined milk yield using the weigh-suckling method and reported an inversely proportional relationship between milk yield and intake as the number of kits increased. Increase in litter size is associated with a decline in quantity of milk share for each kit (Zerrouki et al., 2012; Yuan et al., 2015). In this respect, large sized litters could compromise the nursing ability of does (Vidjannagni et al., 2018).

From results the increase in milk production by increasing litter size might be due to a greater tactile stimulation of the does teats by their bunnies which enhancing the milk secretion and the higher suckling intensity by the larger litters might also led to higher release of oxytocin resulting in complete evacuation of residual milk from the mammary glands (Hafez,2000).

\section{Teats number effect:}

Teats number was important factor affecting milk production in rabbit, with a significant $(\mathrm{P} \leq 0.01)$ in the milk yield during most of the week and total milk yield of the study, except during $2^{\text {nd }}$ week where the effect was 
insignificant(Table 1). Szendro, (2008) found that teat numbers are not connected with milk production. It seems that the mammary gland (milk yield) has the same size of does with different teat numbers but kits have more chance to catch a teat during the short nursing time. Despite of similar milk production their chance to suck some milk is higher in case of 10 teats and he is suggested to mark and select female and male newborn rabbits with 10 treats to improve the productivity. Szendro, et al.,(2012) found that nursing time duration from 2.5 to $3 \mathrm{~min}$,during this short period, kits are able to suck an amount of milk equal to 15 to $20 \%$ of their body weight. Kits suck very strongly. The moment they feel the teat empty, they release it and try to catch another one. Their chances here depend on teat number and litter size. In a 10-kit litter, two kits are waiting for a teat every second if the doe's teat number is only 8 . With 10 teats, all the kits have the opportunity to consume milk.

\section{Genetic correlation:}

In general the genetic correlation between litter size at birth and litter weight were significant, positive and high and ranging from 0.48 to 0.66 except between litter size at birth and litter weight at weaning were low in Table 2 . Whereas the genetic correlation of litter size or litter weight and pre-weaning mortality were not significant and negative (low or high) ranging 0.09 to -0.78 . So genetic correlations are an important measures for the breeder, as it indicates the existence of a relationship between various traits. The correlation coefficient, ranging from -1 to +1 , is a measure of this relationship between traits. As long as the coefficient remains within the range -1 to 0 , the correlation is negative, which means that an improvement in one trait will result in deterioration of another. These results agreement with Sorhue et al., 2014 reported that positive and significant genetic correlations $(r G)(\mathrm{P}>0.05)$ was obtained for litter birth weight and litter size born alive (0.94 and 0.67), litter size born alive and weaning weight (0.89 and 0.61$)$, litter birth weight and 21 day body weight (0.88 and 0.63 ) from sire and dam components respectively. Hassan et al., 2015 who reported that all estimates of genetic correlations among litter weights were high and positive. Thus we may build the strategy on selection criteria on these traits.

All possible genetic correlations among milk traits were significant, positive and of moderate to high and ranging 0.14 to 87 in Table 2.Therefore, can be easily understanding for relationship to other traits to make optimum breeding program for milk traits in rabbits. The genetic improvement in milk yield during first week was accompanied by an increase in milk yield during $2^{\text {nd }}, 3^{\text {rd }}, 4^{\text {th }}$ and total milk yield. 
Table 2.Genetic and phenotypic correlation for litter traits

\begin{tabular}{|l|c|c|}
\hline Trait & $\begin{array}{c}\text { Genetic } \\
\text { correlation }\end{array}$ & $\begin{array}{c}\text { Phenotypic } \\
\text { correlation }\end{array}$ \\
\hline LSB \& LSW & $0.49 \pm 0.26^{* *}$ & 0.55 \\
\hline LSB \& LWB & $0.66 \pm 0.18^{* * *}$ & 0.74 \\
\hline LSB \& LWW & $0.07 \pm 0.31^{* * *}$ & 0.34 \\
\hline LSB \& PM & $0.40 \pm 0.01^{* * *}$ & 0.17 \\
\hline LSW \& LWB & $0.48 \pm 0.28^{* *}$ & 0.51 \\
\hline LSW \& LWW & $0.52 \pm 0.18^{* * *}$ & 0.71 \\
\hline LSW \& PM & $-0.78 \pm 0.01$ & -0.79 \\
\hline LWB \& LWW & $0.35 \pm 0.01^{* *}$ & 0.39 \\
\hline LWB \& PM & $0.09 \pm 0.01$ & 0.08 \\
\hline LWW \& PM & $-0.59 \pm 0.01$ & -0.62 \\
\hline
\end{tabular}

LSB = Litter size at birth; LSW = Litter size at weaning; LWB= Litter weight at birth; LWW= Litter weight at weaning and $\mathrm{PM}=$ Pre-weaning mortality, $\mathrm{P} \leq 0.01$.

\section{Phenotypic correlation:}

The phenotypic correlation between litter size at birth and litter weight were positive and high and ranging from 0.34 to 0.74 are presented in Table 2 . Whereas the phenotypic correlation litter size or litter weight and pre-weaning mortality were negative (low and high) ranging 0.08 to -0.79.Elamin and Yousif, 2011 found that the phenotypic correlations among total born alive, litter size at birth, litter weight at birth and litter size at weaning were positive and significantly high, Such traits are mainly under environmental control and the phenotypic parameters reflect most of the association found among such traits. Sorhue et al., 2014 reported that Phenotypic $(r P)$ between the traits studied (litter size at birth, litter size born alive, litter birth weight and litter weight at weaning) were mostly non-significant $(\mathrm{P}<0.05)$.

All possible the phenotypic correlations among milk traits were positive and of moderate to high and ranging 0.31 to 83 in Table 3.

\section{Selection Indices:}

Phenotypic and genetic variances and covariance and heritability to use for calculating selection indices for litter and milk traits given in Tables 4 and 5.

Several selection indices for litter and milk traits were constructed incorporating litter size at birth $\left(\mathrm{X}_{1}\right)$, litter size at weaning $\left(\mathrm{X}_{2}\right)$, litter weight at birth $\left(\mathrm{X}_{3}\right)$, litter weight at weaning $\left(\mathrm{X}_{4}\right)$ and pre-weaning mortality $\left(\mathrm{X}_{5}\right)$, milk yield during the $1^{\text {st }}, 2^{\text {nd }}, 3^{\text {rd }}$ and $4^{\text {th }}$ week $\left(\mathrm{X}_{1}, \mathrm{X}_{2}, \mathrm{X}_{3}, \mathrm{X}_{4}\right)$ and total milk yield $\left(\mathrm{X}_{5}\right)$ of NZW rabbits, respectively are presented in Tables 6, 7, 8 and 9. 
Table 3. Genetic and phenotypic correlation for milk traits.

\begin{tabular}{|l|c|c|}
\hline Trait & $\begin{array}{c}\text { Genetic } \\
\text { correlation }\end{array}$ & $\begin{array}{c}\text { Phenotypic } \\
\text { correlation }\end{array}$ \\
\hline $\mathrm{MY}_{1} \& \mathrm{MY}_{2}$ & $0.78 \pm 0.14^{* *}$ & 0.51 \\
$\mathrm{MY}_{1} \& \mathrm{MY}_{3}$ & $0.24 \pm 0.17^{* *}$ & 0.46 \\
$\mathrm{MY}_{1} \& \mathrm{MY}_{4}$ & $0.14 \pm 0.33^{* *}$ & 0.31 \\
$\mathrm{MY}_{1} \& \mathrm{TMY}$ & $0.64 \pm 0.10^{* *}$ & 0.74 \\
$\mathrm{MY}_{2} \& \mathrm{MY}_{3}$ & $0.61 \pm 0.11^{* *}$ & 0.56 \\
$\mathrm{MY}_{2} \& \mathrm{MY}_{4}$ & $0.17 \pm 0.28^{* *}$ & 0.31 \\
$\mathrm{MY}_{2} \& \mathrm{TMY}^{* *}$ & 0.78 \\
$\mathrm{MY}_{3} \& \mathrm{MY}_{4}$ & $0.83 \pm 0.06^{* *}$ & 0.38 \\
$\mathrm{MY}_{3} \& \mathrm{TMY}^{* *}$ & $0.76 \pm 0.20^{* *}$ & 0.83 \\
$\mathrm{MY}_{4} \& \mathrm{TMY}^{*}$ & $0.87 \pm 0.06^{* *}$ & 0.55 \\
\hline $\mathrm{MY}_{1} ; \mathrm{MY}_{2} ; \mathrm{MY}_{3} ; \mathrm{MY}_{4}=$ Milk yield during the $1^{\text {st }}, 2^{\text {nd }}, 3^{\text {rd }}$ and $4^{\text {th }}$ week TMY $=$ Total milk yield, \\
$\mathrm{P} \leq 0.01$.
\end{tabular}

Table 4. Phenotypic and genetic variances (on diagonal), covariance (above diagonal) and heritability of litter traits of NZW rabbits.

\begin{tabular}{|l|r|r|r|r|r|c|}
\hline Varieties & LSB & LSW & LWB & LWW & PM & $\mathbf{h}_{\mathbf{a}}$ \\
\hline Phenotypic & & & & & & \\
\hline LSB & 2.9926 & & & & & $0.08 \pm 0.04$ \\
\hline LSW & 1.8541 & 3.7263 & & & & $0.09 \pm 0.01$ \\
\hline LWB & 159.94 & 120.64 & 1563.52 & & & $0.07 \pm 0.03$ \\
\hline LWW & 713.63 & 1134.01 & 57432.90 & 1383218.70 & & $0.09 \pm 0.01$ \\
\hline PM & 2.16 & 17.99 & 1163.57 & 10910.84 & 349.90 & $0.03 \pm 0.01$ \\
\hline Genetic & & & & & & \\
\hline LSB & 0.2426 & & & & & \\
\hline LSW & 0.1141 & 0.2463 & & & & \\
\hline LWB & 11.16 & 8.46 & 1164.72 & & & \\
\hline LWW & 12.96 & 87.63 & 4215.60 & 124697.70 & & \\
\hline PM & 0.6437 & 0.8207 & 56.44 & 583.99 & 10.94 & \\
\hline
\end{tabular}

Litter size at birth (LSB); Litter size at weaning (LSW); Litter weight at birth (LWB); Litter weight at weaning (LWW) and Pre-weaning mortality ratio (PM)was calculated as a percentage of dead young at weaning to the total litter size born. 
Table 5. Phenotypic and genetic variances (on diagonal), covariance (above diagonal) and heritability of milk traits of NZW rabbits.

\begin{tabular}{|l|c|r|r|r|r|r|}
\hline \multicolumn{1}{|c|}{ Varieties } & MY1 & MY2 & MY3 & MY4 & TMY & $\mathbf{h}^{2}{ }_{\mathbf{a}}$ \\
\hline Phenotypic & & & & & & \\
\hline MY1 & 89455.55 & & & & & $0.11 \pm 0.05$ \\
\hline MY2 & 53525.92 & 124126.9 & & & & $0.15 \pm 0.04$ \\
\hline MY3 & 56829.66 & 81773.42 & 174227.87 & & & $0.25 \pm 0.05$ \\
\hline MY4 & 31352.92 & 36924.8 & 54554.80 & 116827.09 & & $0.06 \pm 0.04$ \\
\hline TMY & 227716.87 & 285460.0 & 351923.96 & 195130.61 & 1080643.21 & $0.14 \pm 0.01$ \\
\hline Genetic & & & & & & \\
\hline MY1 & 9537.89 & & & & & \\
\hline MY2 & 10502.43 & 18853.8 & & & & \\
\hline MY3 & 4970.52 & 17647.96 & 44624.82 & & & \\
\hline MY4 & 1159.81 & 1963.46 & 14256.33 & 7798.1 & & \\
\hline TMY & 33747.67 & 45710.1856711 .95 & 20938.31 & 160134.6 & \\
\hline
\end{tabular}

MY1, MY2, MY3 and MY4 $=$ Milk yield during the $1^{\text {st }}, 2^{\text {nd }}, 3^{\text {rd }}$ and $4^{\text {th }}$ week, respectively and $\mathrm{TMY}=$ Total milk yield

All possible combinations, the values of $b(b=$ Partial regression coefficient) for each of a total of 11 indices were large differences, even, in some of the indices were low, moderate and high and were negative and positive in other indices for litter and milk traits in Tables 6 and 8. These results were indicated the values b's depending on phenotypic, genetic variances and covariance, heritability and relative economic value. High values of b's might be attributed to positive genetic correlations between different traits and its high relative economic value and low values of b's might be refer to low heritability. Khalil, 1986 found that the large differences in index weights for litter size at weaning in index $\mathrm{I}_{1} \mathrm{v} . \mathrm{I}_{3}$ and $\mathrm{I}_{4} \mathrm{v} . \mathrm{I}_{6}$, and he suggested the reason is that litter size at birth has been measured in indices $\mathrm{I}_{1}$ and $I_{4}$ not in $I_{3}$ or $I_{6}$ and it contributes substantially to total genetic gain in aggregate genotype of $\mathrm{I}_{1}$ and $\mathrm{I}_{4}$.

Relative efficiency $\left(R_{I H}\right)$ in litter traits (Table 6) were high for $\mathrm{I}_{1}$ (based on five traits) to other indices and recommended for use to maximize response and apply selection on this index.

$$
I_{1}=14.07 X 1+17.99 \times 2+4.88 \times 3+0.500 X 4+18.50 \times 5
$$


The high efficiency of index may be attributed to high phenotypic and genetic variances of those traits. Khalil, 1986 found that the chief measure of the utility of an index is its correlation with aggregate genotype, $r_{I H}$, where the genetic response to selection is proportional to this correlation, with corresponding $\mathrm{r}_{\mathrm{IH}}$, the first index $\left(\mathrm{I}_{1}\right)$, which incorporated five varieties(litter size at weaning, mean bunny weight at weaning, pre-weaning mortality, litter size at birth and litter weight at birth ) and the forth index $\left(\mathrm{I}_{4}\right)$, which incorporated four varieties out five have $\mathrm{r}_{\mathrm{IH}}$, values of 0.31 and 0.48in Bauscat and Giza White were the most accurate while $\mathrm{I}_{2}, \mathrm{I}_{5}, \mathrm{I}_{7}$ and $\mathrm{I} 8$ were the lowest.

Relative efficiency $\left(R_{I H}\right)$ in milk traits (Table 6) were high for $I_{2}$ (based on four traits) to other indices and recommended for use to maximize response and apply selection on this index.

$$
\mathrm{I}_{2}=-0.109 \mathrm{X} 1+0.366 \mathrm{X} 2+1.71 \mathrm{X} 3+0.141 \mathrm{X} 4 \quad 0.4483
$$

The expected genetic gain, $(\Delta \mathrm{G})$ in each trait for litter traits are presented in Table 7 . The expected genetic gain changes in litter size at birth was low in all of the indices used and ranging from -0.031 to 0.129 young, in litter size at weaning was low and ranging from 0.065 to 0.100 young, in litter weight at birth was moderate or high and ranging 3.71 to $9.34 \mathrm{~g}$, in litter weight at weaning was high and ranging from 108.99 to $131.65 \mathrm{~g}$ and in preweaning mortality was ranging from 0.282 to 1.30 young. From these pervious results could be genetic improvement for doe productivity of New Zealand White rabbits achieved through selection for litter weight at birth and litter weight at weaning. Khalil, 1986 found that the expected genetic gain, $(\Delta \mathrm{G})$ in any trait achieved by selection differential of one standard deviation in the index is the product of the genetic standard deviation for the trait and correlation between the index and the genetic value for such trait, However, the magnitude of the expected genetic change in litter size at weaning was slight in all of the indices used, due to the low heritability values for this trait, all ranging from 0.05 to 0.06 young for the Bauscat and 0.09 to 0.10 young for the Giza White. Similarly, the estimate of expected genetic change in mean bunny weight at weaning was low in Bauscat rabbits for the same reason. On the other hand, the expected genetic change in mean bunny weight at weaning of Giza White rabbits was high from using the different indices, all ranging from 20.4 to $26 \mathrm{~g}$ per bunny. Accordingly, it could be stated that considerable genetic improvement for doe productivity of Giza White rabbits might be achieved through selection for mean bunny weight at weaning. 
Table 6. Selection indices, weighting factors (values of b) in each trait and relative efficiency $\left(\mathrm{R}_{\mathrm{IH}}\right)$ in litter traits and pre-weaning mortality of NZW rabbits.

\begin{tabular}{|c|c|c|}
\hline Index no. & Values of $\mathbf{b}$ & $\mathbf{R}_{\mathrm{IH}}$ \\
\hline I1 & $-14.07 \mathrm{x} 1_{1}+17.99_{\mathrm{x} 2}+4.88_{\mathrm{x} 3}+0.50 \mathrm{x}_{\mathrm{x}}+18.50_{\mathrm{x} 5}$ & 0.3687 \\
\hline $\mathrm{I} 2$ & $13.899_{\mathrm{x} 1}+14.60_{\mathrm{x} 2}+1.32_{\mathrm{X} 3}+0.390_{\mathrm{x} 4}$ & 0.3248 \\
\hline $\mathrm{I} 3$ & $-2.76 \times 1+1.22 \times 2+0.350 \times 3-0.007 \times 5$ & 0.2691 \\
\hline I4 & $-19.33_{\mathrm{x} 1}+15.93 \mathrm{x} 2+0.356_{\mathrm{x} 4}-7.62 \mathrm{x} 5$ & 0.3248 \\
\hline I5 & $-6.95 \mathrm{x} 1+14.19 \mathrm{x} 2+0.277 \mathrm{x} 4$ & 0.3113 \\
\hline I6 & $0.787 \mathrm{x} 1+0.138 \mathrm{x} 2+0.317 \mathrm{x} 5$ & 0.2410 \\
\hline I7 & $-1.37 \mathrm{xl}_{1}-0.128 \mathrm{x} 2+0.253 \mathrm{x} 3$ & 0.2733 \\
\hline I8 & $0.0866_{x 1}+0.047 \mathrm{x} 2$ & 0.2655 \\
\hline I9 & $0.089 \mathrm{x} 1+0.01_{\mathrm{x} 3}$ & 0.2740 \\
\hline $\mathrm{I} 10$ & $15.58 \mathrm{x1}+0.194 \mathrm{x} 4$ & 0.3247 \\
\hline I11 & $0.819 \mathrm{xl}+0.112 \mathrm{x5}$ & 0.2102 \\
\hline
\end{tabular}

$\mathrm{X}_{1}=$ Litter size at birth; $\mathrm{X}_{2}=$ Litter size at weaning; $\mathrm{X}_{3}=$ Litter weight at birth; $\mathrm{X}_{4}=$ Litter weight at weaning and $X_{5}=$ Pre- weaning mortality.

Table 7. Expected genetic gain, $g(\Delta G)$ in each trait in litter traits and preweaning mortality of NZW rabbits.

\begin{tabular}{|l|c|c|c|c|c|}
\hline \multicolumn{1}{|c|}{ Index no. } & $\boldsymbol{\Delta} \mathbf{G}_{\mathbf{X} \mathbf{1}}$ & $\boldsymbol{\Delta} \mathbf{G}_{\mathbf{X} \mathbf{2}}$ & $\boldsymbol{\Delta} \mathbf{G}_{\mathbf{X} \mathbf{3}}$ & $\boldsymbol{\Delta} \mathbf{G}_{\mathbf{X} \mathbf{4}}$ & $\boldsymbol{\Delta} \mathbf{G}_{\mathbf{X} \mathbf{5}}$ \\
\hline I1 & 0.072 & 0.089 & 5.09 & 131.65 & 0.194 \\
I2 & 0.024 & 0.070 & 3.71 & 111.96 & - \\
I3 & 0.084 & 0.096 & 9.34 & - & 0.274 \\
I4 & 0.047 & 0.073 & - & 114.54 & 0.282 \\
I5 & -0.031 & 0.065 & - & 108.99 & - \\
I6 & 0.077 & 0.068 & - & - & 1.30 \\
I7 & 0.083 & 0.065 & 9.34 & - & - \\
I8 & 0.123 & 0.100 & - & - & - \\
I9 & 0.129 & - & 8.14 & - & - \\
I10 & 0.072 & - & - & 113.69 & - \\
I11 & 0.103 & - & - & - & 0.672 \\
\hline
\end{tabular}

$\mathrm{X}_{1}=$ Litter size at birth; $\mathrm{X}_{2}=$ Litter size at weaning; $\mathrm{X}_{3}=$ Litter weight at birth; $\mathrm{X}_{4}=$ Litter weight at weaning and $\mathrm{X}_{5}=$ Pre-weaning mortality. 
Table 8. Selection indices, weighting factors (values of b) in each trait and relative efficiency $\left(R_{I H}\right)$ in milk yield and total milk yield of NZW rabbits.

\begin{tabular}{|l|c|c|}
\hline .Index no. & Values of b & RIH \\
\hline I1 & $-0.073 \mathrm{X} 1+1.71 \mathrm{X} 2+3.37 \mathrm{X} 3+0.284 \mathrm{X} 4-0.115 \mathrm{X} 5$ & 0.4221 \\
I2 & $-0.109 \mathrm{X} 1+0.366 \mathrm{X} 2+1.71 \mathrm{X} 3+0.141 \mathrm{X} 4$ & 0.4483 \\
I3 & $0.288 \mathrm{X} 1+2.05 \mathrm{X} 2+1.87 \mathrm{X} 3-0.073 \mathrm{X} 5$ & 0.4118 \\
I4 & $-0.742 \mathrm{X} 1+0.410 \mathrm{X} 2-0.321 \mathrm{X} 4+0.938 \mathrm{X} 5$ & 0.3784 \\
I5 & $0.279 \mathrm{X} 1+0.480 \mathrm{X} 2+0.182 \mathrm{X} 4$ & 0.3274 \\
I6 & $0.080 \mathrm{X} 1+1.05 \mathrm{X} 2+0.294 \mathrm{X} 5$ & 0.3860 \\
I7 & $0.220 \mathrm{X} 1+0.706 \mathrm{X} 2+0.593 \mathrm{X} 3$ & 0.4216 \\
I8 & $0.240 \mathrm{X} 1+0.359 \mathrm{X} 2$ & 0.3943 \\
I9 & $0.186 \mathrm{X} 1+0.396 \mathrm{X} 3$ & 0.3997 \\
I10 & $0.151 \mathrm{X} 1+0.155 \mathrm{X} 4$ & 0.2605 \\
I11 & $-0.117 \mathrm{X} 1+0.324 \mathrm{X} 5$ & 0.3667 \\
\hline
\end{tabular}

$\mathrm{X}_{1} ; \mathrm{X}_{2} ; \mathrm{X}_{3} ; \mathrm{X}_{4}=$ Milk yield during the $1^{\text {st }}, 2^{\text {nd }}, 3^{\text {rd }}$ and $4^{\text {th }}$ week $\mathrm{X}_{5}=\mathrm{TMY}$.

The expected genetic gain, $(\Delta \mathrm{G})$ in each trait for milk traits are presented in Table 9. The expected genetic gain changes were high in milk yield during the $1^{\text {st }}$, $2^{\text {nd }}, 3^{\text {rd }}, 4^{\text {th }}$ week and total milk yield and ranging 14.39 to $34.77 \mathrm{~g}, 42.33$ to $54.26 \mathrm{~g}$, 83.71 to $105.66 \mathrm{~g}, 10.45$ to $32.70 \mathrm{~g}$ and 143.60 to $151.76 \mathrm{~g}$.

Table 9. Expected genetic gain, $\mathrm{g}(\Delta \mathrm{G})$ in each trait in milk yield and total milk yield of NZW rabbits.

\begin{tabular}{|c|c|c|c|c|c|}
\hline Index no. & $\boldsymbol{\Delta} \mathbf{G}_{\mathbf{X} \mathbf{1}}$ & $\boldsymbol{\Delta} \mathbf{G}_{\mathbf{X} \mathbf{2}}$ & $\boldsymbol{\Delta} \mathbf{G}_{\mathbf{X} \mathbf{3}}$ & $\boldsymbol{\Delta \mathbf { G } _ { \mathbf { X } \mathbf { 4 } }}$ & $\boldsymbol{\Delta} \mathbf{G}_{\mathbf{X} \mathbf{5}}$ \\
\hline I1 & 18.22 & 49.70 & 102.40 & 29.45 & 146.98 \\
I2 & 14.39 & 45.42 & 105.66 & 32.70 & - \\
I3 & 24.40 & 54.66 & 88.53 & - & 149.32 \\
I4 & 21.63 & 47.69 & - & 19.41 & 151.76 \\
I5 & 31.43 & 49.01 & - & 10.45 & $?$ \\
I6 & 28.76 & 42.33 & & & 143.60 \\
I7 & 26.24 & 54.26 & 83.71 & & \\
I8 & 34.77 & 53.30 & - & & \\
I9 & 19.23 & - & 93.05 & & \\
I10 & 20.81 & & & 16.70 & \\
I11 & 21.32 & & & & 146.62 \\
\hline
\end{tabular}

$\mathrm{X}_{1} ; \mathrm{X}_{2} ; \mathrm{X}_{3} ; \mathrm{X}_{4}=$ milk yield during the $1^{\text {st }}, 2^{\text {nd }}, 3^{\text {rd }}$ and $4^{\text {th }}$ week $\mathrm{X}_{5}=\mathrm{TMY}$. 
From these results could be genetic improvement for doe productivity of New Zealand White rabbits achieved through selection for milk yield during the $1^{\text {st }}$ week, lead to improvement for milk production during $2^{\text {nd }}, 3^{\text {rd }}, 4^{\text {th }}$ week and total milk yield.

\section{CONCLUSION:}

Results can be concluded in the following practical things which may be helpful as guides to for rabbit breeders; Milk production was higher in winter months than other seasons. In generally the insignificant effect of parity on milk production. The higher milk production in the does with larger litters might be due to the increase in the amount of milk consumed by increasing the number of young which stimulate the mammary gland to increase its production from milk. Select female and male new born rabbits with 10 treats to improve the productivity. Genetic correlation are helpful as guides to selection. For example, by offer encouragement to the rabbit breeder to select for litter size and litter weight traits at earlier ages. The genetic improvement in milk yield during first week was accompanied by an increase in milk yield during $2^{\text {nd }}, 3^{\text {rd }}, 4^{\text {th }}$ and total milk yield. For litter traits recommended for use to maximize response and apply selection on index $\mathrm{I}_{1}$ (based on five traits). For milk traits recommended for use to maximize response and apply selection on this index, $\mathrm{I}_{2}$ (based on four traits).

\section{REFERENCES}

Abd-El-Monem, U.M. (2009). Effect of feeding system, dietary copper supplementation and climatic conditions on performance of adult female and male rabbits. Egyptian Journal Of Rabbit Science, 19(1):51-70.

Ahmed, E. G., (1997).Productive performance of different exotic strains of rabbits. Ph. D. Thesis, Faculty of Agriculture, Suez Canal University, Ismailia, Egypt.

Ayyat, M S, Marai, I F M, El-Sayaid G H A (1995). Genetic and non-genetic factors affecting milk production and preweaning litter traits of New Zealand White does under Egyptian conditions. World Rabbit Science, 3: 119-124.

Boldman, K G, Kriese , A, Van Vleck, L D, Van Tassell, C P and Kachman, S D (1995). A manual for use of MTDFREML. A set of programs to obtain estimates of variances and covariances [DRAFT]. U. S. Department of Agriculture, Agricultural Research Service, USA.

Elamin, K. M. and Yousif, I. A. (2011). Evaluation of litter traits in Sudanese rabbits. Livestock Research for Rural Development, 23 (9). 
El-Sayiad, G.A., Habeeb, A.A.M., El-Maghawry, A.M., 1994. A note on the effect of breed, stage of lactation and pregnancy status on milk composition of rabbits. Anim. Sci., 58(1), 153-157.

El-Sayiad, G.A., Habeeb, A.A.M., El-Maghawry, A.M., 1994. A note on the effect of breed, stage of lactation and pregnancy status on milk composition of rabbits. Anim. Sci., 58(1), 153-157.

El-Sayiad, G. H. A.(1994). A study on milk production of New Zealand White and Californian rabbits under Egyptian conditions. Egyptian Journal of Rabbit Science, 4 (1): 47-59.

Gyovai P., Nagy I., Gerencser Z., Matics Z., Radnai I., Donko T.,Bokor A., Farkas J., Szendro, Z. (2012). Genetic parameters for litter weight, average daily gain and thigh muscle volume measured by in vivo computer tomography technique in Pannon White rabbits. Livestock Sci. 144:119123.

Hassan, N.S., Abdel-Ghany, A.M. and Sabri, H.M.(2015). Genetic Parameters of the Newly-Developed Egyptian APRI Rabbit Line Raised Under NorthDelta Environment Using DF-REML Animal Model 1 Litter Weight Traits. E C Veterinary Science, 1(1): 30-46.

Hafez, E.S.E. (2000). Reproduction In Farm Animals. 6th ED.

Hazel, L.N. (1943). The genetic basis for constructing selection indexes .Genetics 28: 476- 490.

Iraqi, M. M. and Youssef, Y. M. K. (2006). Genetic analysis for milk production traits in New Zealand White rabbits raised in Egypt. Egyptian Journal of Rabbit Science, 16(1):1-13.

Kacsala, L., Matics, ZS., Kasza, R., Gerencser, ZS., Szendro, ZS. (2015). Milk supply of rabbit kits. Article (PDF A vailable) In Poljoprivreda, 21 (1 supplement) : 90-92.

Khalil, M. H., (1986). Selection indices for rabbit improvement .J. Agric. Sci.Ccamb.,537-548.

Lamont, S.J. (1991). Selection For Immune Response In Chickens. Presented at the 40 Annual National Breeder Round Table. May 2!3. St. Louis, Missouri.

Kolawole, S.O., Kikelomo, A.M., Taiwo, O.J., Sunday, F.S., (2013). Yield, intake and chemical profile of milk of commercially available rabbits at first parity. J. Agr. Allied Sci., 2(4), 1-7.

Mintab, (1991). Faculty of Economim and Adminstartive. S. H.A.E. OnlineDoc. 
McNitt, J.I. and Lukefahr,S.D. (1990). Effect of breed, parity, day of lactation and number of kits on milk production of rabbits. Journal Of Animal Science. 68: 1505-1512.

Mahmoud, E.A.A.(2013). A study on some factors affecting milk yield in New Zealand White rabbits under Egyptian conditions, Benha Veterinary Medical Journal, Vol. 25, No., Deci. 13-22.

SAS. (2003). SAS Online Doc 9.13 SAS Institute Inc.,Cary, NC, USA.

Soliman, M.M. (2008). Productive and reproductive performance of doe rabbits as affected by feeding type and season of kindling under Egyptian conditions. Egyptian Journal Of Rabbit Science.18(2): 117-134.

Sorhue, U.G.; Mmereole, F. U. C.B; Irikefe-Ekeke, E.P.C; Wakwo, U.N.S.(2014).Genetic analysis of some economic traits in a composite breed of domestic rabbits reared in a tropical environment. Nigerian Journal of Genetic, Volume 28, Issuez, July: 34-37.

Szendrő, Zs. (2008). Improving of reproductive performance of rabbit does in small and medium scale rabbit farms. recommendations for developing countries Acta Agraria Kaposváriensis, 12(1): 1-23.

Szendrö, Zs., Szendrö, K. and Dalle Zotte, A. (2012). Management of Reproduction on Small, Medium and Large Rabbit Farms: A Review.AsianAustralas, J. Amin. Sci, May, 25 (5): 738-748.

Yamani, K.A.O.; Daader, A.H. and Askar, A.A. (1992). Non genetic factors affecting rabbit production in Egypt. Options Mediterranean's, Seri Seminaries. 17: 159-172.

Yuan, T., Zhu, Y., Shi, M., Li, T., Li, N., Wu, G., Bazer, F.W., Zang, J., Wang, F., Wa ng, J., (2015). Within-litter variation in birth weight: Impact of nutritional status in the sow J. Zhejiang Univ. Sci. B., 16(6), 417-435.

Vidjannagni, D.S.; Toleba, S.S.; Sina, H.; Mahamadou, D.; Adenile, A.; Natonnagnon, U.; Daga, F.D.; Harouna, H.; Moussa, L.B. (2018). Appetibility and effect of neem (Azadirachta indica) leaf foods on weight performance and viability of pre-weaning rabbits. Int. J. Livest. Prod., 9(1): $1-8$.

Zerrouki, N., Chibah, K., Amroun, T., Lebas, F., (2012). Effect of the average kits birth weight and of the number of born alive per litter on the milk production of Algerian white population rabbit does. Proceeding of the $10^{\text {th }}$ World Rabbit Congress, September 3- 6, Sharm El-Sheikh, Egypt. 351-355. 


\section{العوامل المؤثزة على أنتاج اللبن وتطبيق أدلة الانتخاب لتحسين الصفات

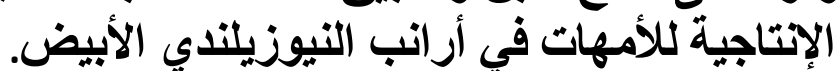

أميرة سليمان الدغيدى.

معهد بحوث الإنتاج الحيو اني، مركز البحوث الزر اعية، الجيزة- مصر

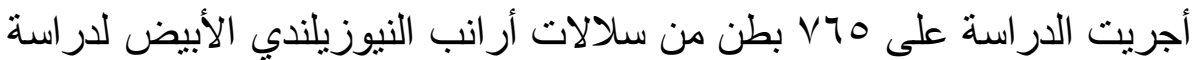

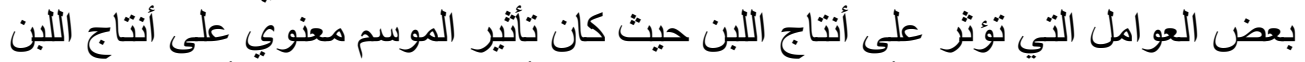

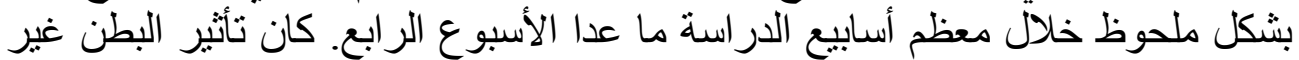

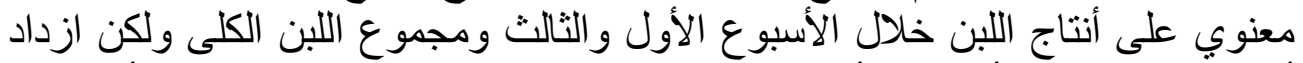

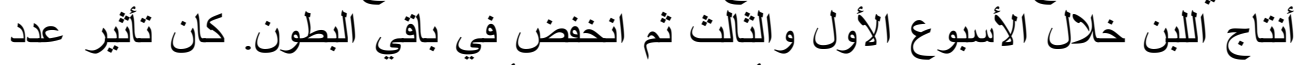

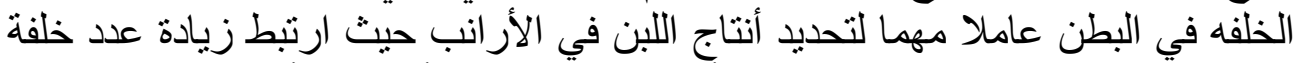

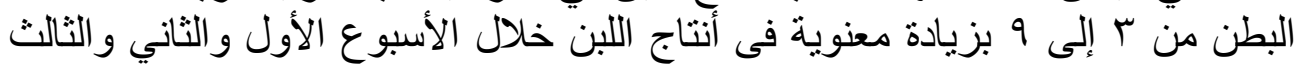

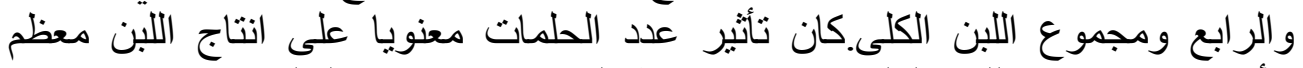

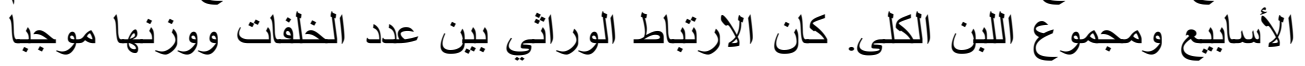

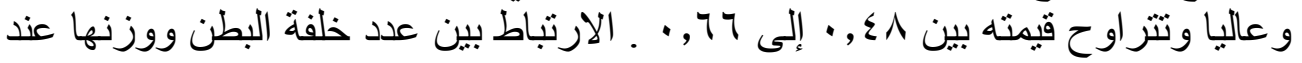

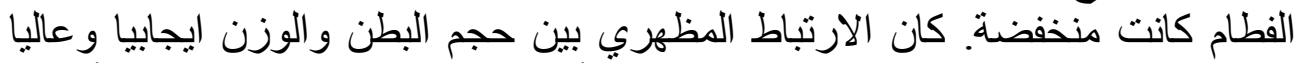

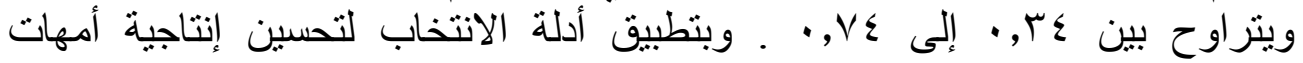

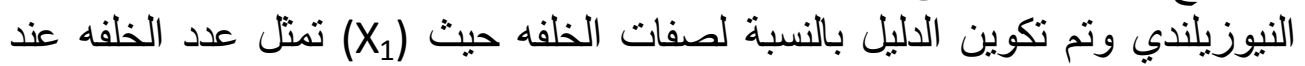

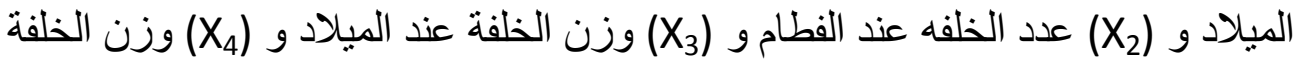

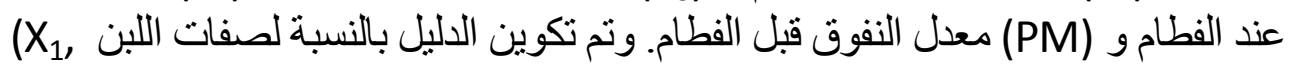

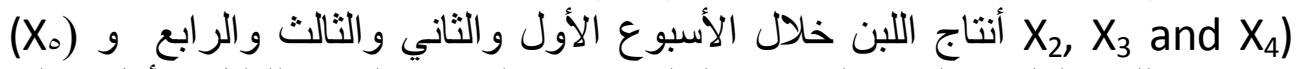

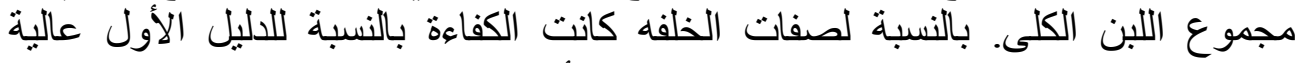

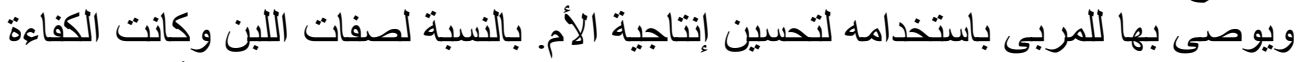

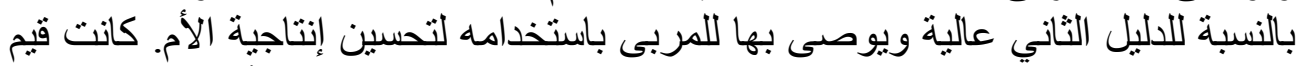

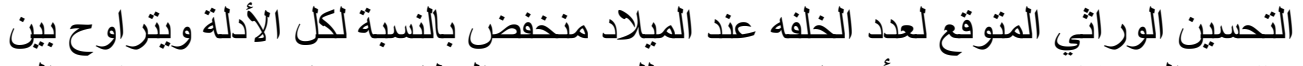

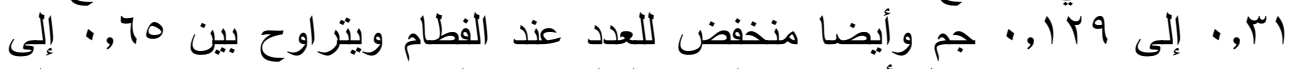

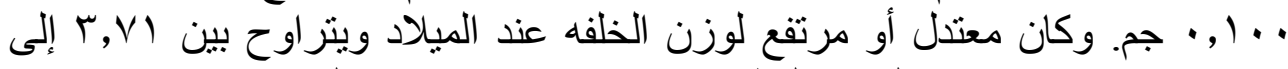

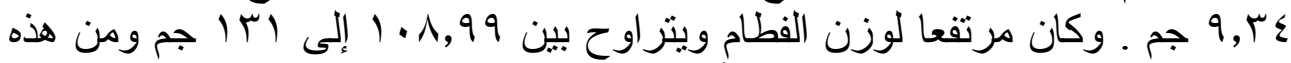

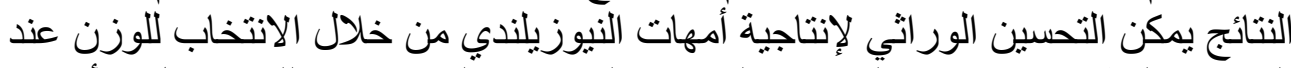

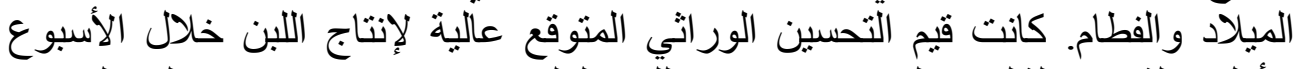

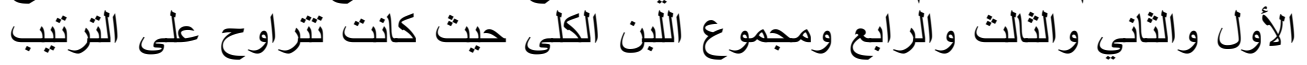


q

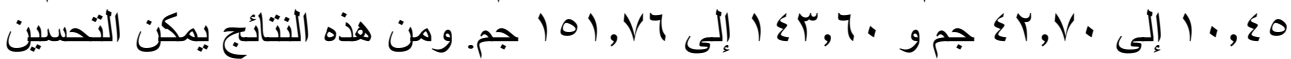

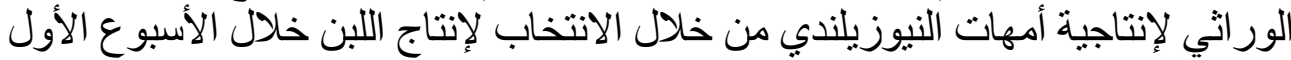

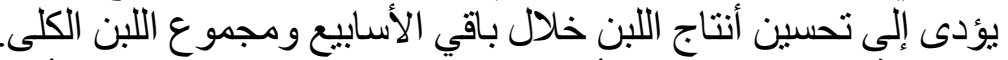

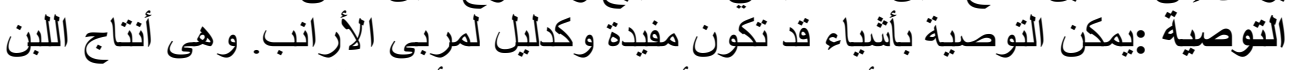

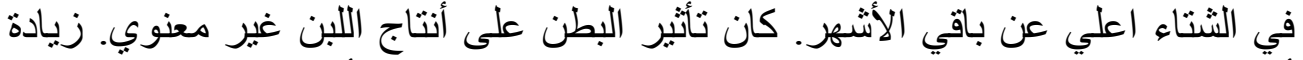

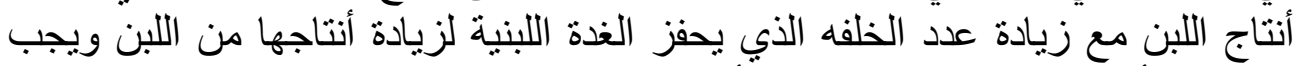
انتخاب الأرانب الذكور والإناث من أمهات لها ـ الأ حلمات لتحسين الإنتاجية. الصفات

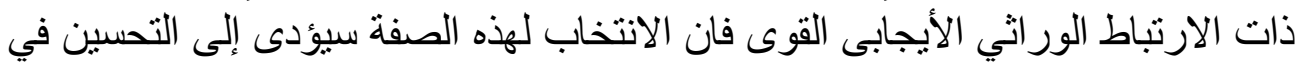

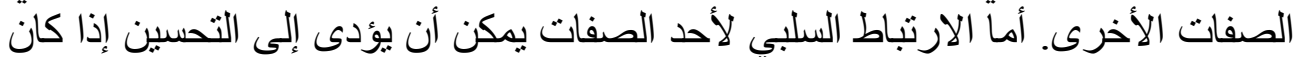

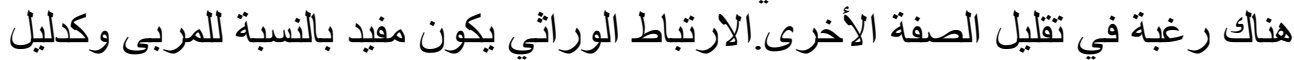

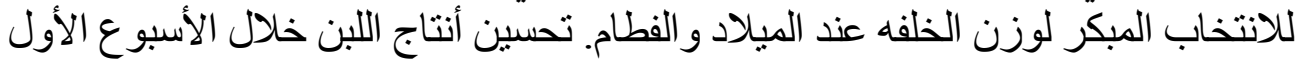

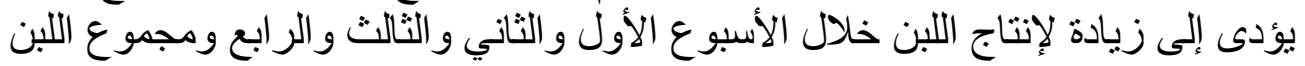

